\title{
Focusing on Customer: Relationships between Design and Market Orientation
}

\author{
${ }^{1}$ Sanja Rocco, ${ }^{2}$ Aleksandra Pisnik \\ ${ }^{1}$ Zagreb School of Business, Croatia \\ ${ }^{2}$ Faculty of Economics and Business, University of Maribor, Slovenia
}

\begin{abstract}
Understanding and meeting consumer's needs, wants and desires is of the key importance for success in the market. While market orientation is well researched, the role of design within marketing has been neglected. Therefore the main purpose of this study is to develop the initial conceptual model researching relationships between design and market orientation. The initial conceptual model based on theory is proposed as the starting point for future research. The preliminary qualitative research about the potentials of design orientation from the managers', as well as the designers' perspectives has been executed at this stage of the research. Results show that differences between the two groups of examinees exist, mostly in their perception of design. The proposed design orientation-market orientation model contributes to both marketing and design scholars, as well as marketers, designers, and managers in practice. The results of this study may provide a basis for future research on the topic.
\end{abstract}

Keywords: Conceptual model, Design management, Design orientation, Market orientation, Relationships

\section{INTRODUCTION}

Marketing concepts have constantly been developing throughout history. Today, marketing engages all an organization's resources, skills, products, services, and thinking to understand and meeting consumer's conscious and latent needs. New approaches research exchange relationships based on characteristics of the actors in the process of exchange and on mutuality, within constraints of the social environment. Current developments in social exchange theory offer new directions for marketing thought by incorporating and going beyond existing concepts of relationship marketing and co-creation of value (Bagozzi, 2011). Customers are looking for added value, and their expectations are getting more and more sophisticated, while in most industries technical and functional qualities are taken for granted. When responding to customer needs, recent marketing literature mentions three crucial terms: market orientation, customer orientation, and design orientation (Gummesson, 1991; Moll, Montana, Guzman, \& Praallada, 2007; Coley, Mentzer \& Cooper, 2010; Venkatesh, Digerfeld-Mansson, Brunel \& Chen, 2012). Bringing not only functional dimensions but also the emotional experience, design is becoming an important competitive advantage. The main thesis of this paper is that a strong link exists between market orientation and design orientation and that both have a great impact on the success of new product and the firm in the market. The focus on the customer gives the design an even more important role, becoming very efficient when integrated into all levels of the company. Therefore, the potentials of design need to be taken into account by marketing scholars and managers.

In general, design is considered an important element of marketing (Kotler \& Rath, 1984; Dumas \& Mitzberg, 1991; Blaich \& Blaich, 1993). While the role of other functions within marketing is continuously researched and measured, it is obvious that the role of design has been neglected. 


\section{Sanja Rocco, Aleksandra Pisnik \\ Focusing On Customer: Relationships Between Design And Market Orientation}

The design is still often treated only as functional (Schroeder, 2002), aesthetic (Schmitt and Simonson, 1998), or ergonomic characteristics of physical products (Srinivasan, Lilien \& Rangaswami, 2006). Most managers are not aware of design potential when designing processes and do not use design as a strategic tool (Verizer \& Borja de Mozota, 2005; Borja de Mozota, 2009). However, recent market-oriented (Coley et al., 2010; Jaworski \& Kohli, 1993; Gummesson, 1991) and design-oriented studies (e.g., Moll et al., 2007; Venkatesh et al., 2012) about the role of design consider it to be the essence of innovation and a powerful strategic tool. To be successful in the same way as marketing, design has to be integrated into all functional parts of an organization (Borja de Mozota, 2003a; Best, 2010). The impression is that design management has not yet been accepted by broader marketing management specialists, educators, or managers, as a possibility to innovate for not only tangible products but also brands and intangible processes (Borja de Mozota, 2011). Studies about the influence of design on customer satisfaction, product development, and innovation or business performance also exist, but there is a lack of research about the relationship and possible role of design in strategic marketing, as well as of possibilities and potential of the common platform for closer collaboration.

The originality of this paper lies in the fact that it addresses the influence of market orientation on design orientation as well as its relation to the customer orientation, which, according to Narver and Slater (1990), is a component of MO. Customer orientation is the set of beliefs that puts the interest of the client first, while not excluding those of all other stakeholders, in order to develop a long-term profitable enterprise (Deshpande, Farley \& Webster Jr., 1993). Second, the conceptual model provides the context for empirical research of direct relationships between market and design orientation as well as indirect relationships with perceived value of design for the customer and the company. Understanding design potentials and design implementation efficiency when integrated at all levels of an organization, in different industries, allows marketers and managers to achieve more success, focusing on customers' needs at the same time. The paper consists of theoretical background with literature review, development of a conceptual model, qualitative research results, discussion, limitations, and suggestions for future research.

\section{THEORETICAL BACKGROUND}

Market orientation can simply be defined as the implementation of the marketing concept, generating market information within the entire organization regarding the current and future needs of customers and clients (Kohli, Jaworski \& Kumar, 1990). The majority of studies from the 1990 s suggest that market orientation is related to superior performance, sales growth, and newproduct success (Atuahene-Gima, 1995; Desphande \& Farley, 1998; Han, Yun, Kim \& Cho, 1998; Jaworski et al., 1993; Slater \& Narver, 1994). Some authors also suggest that market orientation is a driver of innovation (Berthon, Hulbert \& Pitt, 1999), or research and development activities (Frosch, 1996).

However, market orientation consists not only of so-called responsive market orientation led by customers' conscious needs they are able to express, but also of so-called proactive market orientation, where we consider latent, future customer needs, the ones they are not aware of and which are crucial for developing products and services novel to the market (Slater \& Narver, 1998; Bodlaj, Coenders, \& Žabkar, 2012). A successful market-oriented behavior should be supported and guided by a market-oriented culture (Deshpandé et al., 1998; Slater \& Narver, 1994). Market orientation is positively related to some strategic orientations. To be successfully implemented, all alternative orientations should be guided by the necessary underlying system of beliefs (Grinstein, 2008).

The research by Narver, Slater, and MacLahlan (2004) deals with the concept of market orientation and its relationship with new product success. Their findings show the positive relation between proactive market orientation and innovations, also supporting the significant relationship to new product success in the market, so we presume that the same goes with design orientation. 


\author{
Sanja Rocco, Aleksandra Pisnik \\ Focusing On Customer: Relationships Between Design And Market Orientation
}

However, the four variables of market orientation proposed by Laffertyand Huit (2001) and accepted by Moll et al. (2007) are also incorporated in our conceptual model. According to Narver et al. (2004), latent needs are universal and, to avoid price competition, a business must move beyond customers' expressed needs to the latent ones, exceeding the expectations of the customers to be able to attract and retain them. This is the right opportunity for design-driven innovation. There are three basic types of innovations: incremental, which exploits existing forms or technologies through small changes or improvements (and are usually called redesign of products); modular innovation, within one or more components or systems; and radical innovation which is transformational, upgrading existing knowledge, capabilities, or technologies to create something new (Best, 2010). From that point of view, and considering Olson, Slater, and Cooper's (2000) categorization of product innovation closely connected with the design process, namely new-to-the-world products, line extensions, me-too products, and product modifications, are taken into account.

In general, design orientation has been defined as the process in which design is a crucial factor of integrating different elements in different levels of a company, focused on the customers' conscious and latent needs. It is seen as an organizational model that uses design throughout the company as a transformational process. Design orientation represents an organizational vision and includes the set of conscious, reflective, and creative ways of conceiving, planning, and making of products and services that generate value for the customers and which enable them to engage in their individual or social endeavors, whether these endeavors be utilitarian, functional, material, communicative, symbolic, or experiential (Venkatesh et al., 2012). It has been identified as a factor integrating decisions at different levels of an organization and involving customers as a key element (Bloch, Brunel, \& Arnold, 2003; Moll et al., 2007). Four trends of design orientation are relevant for differentiation in the field of marketing: design in technologically oriented industries, design in non-technological, more craft-oriented industries, the design of service-oriented environments, and brand design. Design as an element is essential for all of them, but its knowhow is different in the four fields (Venkatesh et al., 2012). The design is the vital part of entrepreneurship and design orientation plays a significant positive role in business performance. It is an important factor of products differentiation in the market. Design orientation can also be described as a strategic managerial approach based on choosing design as a source of competitive advantage (Borja de Mozota, 2003a). Design-oriented companies are those that incorporate their design process into their business strategy (Moll et al., 2007).

Design orientation is positively related to a proactive business strategy based on consumer needs and design-driven innovation, which enables their receptivity to market change, even without significant financial investments in expensive technological improvements, which is especially important for SMEs with restricted resources. Using design and design techniques at all levels of the company provides innovations in products, services, processes, and better performance in the market, bringing benefits to all stakeholders involved (Best, 2006). It is considered to be the core innovation tool (Von Stamm, 2008; Borja de Mozota, 2003b). However, design orientation and design implementation are also related to the environment in which a company operates, including social, political, and economic circumstances, design tradition, education, and national design policy. The challenge is to propose a new model of managing design that has been incorporated into the marketing model, which could bring better performance in different environments.

\title{
3. DEVELOPMENT OF A CONCEPTUAL MODEL
}

Comparison of the design-orientation literature (Moll et al., 2007; Chitturi, Raghunattan \& Mahajan, 2008; Srinivasan et al., 2006; Verizer et al., 2005) and market-orientation literature (Gummesson, 1991; Kohli, Jaworski \& Kumar, 1990, 1993) indicates that customer-centered product, as well as service design strategies, are critical to superior market performance and success. Many authors discuss that market orientation has a positive impact on a company's economic result in the market (Narver \& Slater, 1990; Jaworski et al., 1993; Kohli et al., 1993; Kahn, 2001; Snoj, Milfelner \& Gabrijan, 2007). 


\section{Sanja Rocco, Aleksandra Pisnik \\ Focusing On Customer: Relationships Between Design And Market Orientation}

Additionally, it has been proven that there is a relationship between investing in design and improved business results (Black \& Baker, 1987; Sisodia, 1992; Bruce, Potter, \& Roy, 1995; Ulrich \& Pearson, 1998; Slater \& Narver, 2000; Gemser \& Leenders, 2001; Borja de Mozota, 2003b; Design Council, 2004; Hertenstein, Platt \& Veryzer, 2005).

Slater and Narver (2000) suggest that market orientation is one component of the architecture of a learning organization that leads to a superior learning capability. They believe that this replication provides strong support for the existence of a positive relationship between market orientation and performance, and future research should focus on the processes for developing and reinforcing a market-oriented culture and for implementing it through organizational structure, systems, capabilities, and strategies. Most design management research results found that design improves the performance of innovation, whether or not they are technological (Borja de Mozota, 2003b; VonStamm, 2008), and also improves a company's communication policy (Best, 2006). However, most research includes corporate leadership (managers and CEOs), but there have not been significant studies among designers about their knowledge and understanding of design management. The main goal is first to develop a conceptual model of relationships based on existing literature and preliminary qualitative research, and in the second phase to perform empirical testing of the proposed model. In the presented paper, we are focused on the first phase.

The basis of the new initial design-market orientation conceptual model is the existing market orientation model in relation to new product (and service) success (Narver et al., 2004) combined with the managerial model of design (Moll et al., 2007), where market orientation and design orientation are put into a relationship. It is the result of an empirical qualitative research undertaken in three Spanish industries concerning design orientation, market orientation, and design management. These three categories are put in the relationship, offering a new revised model of design management. However, the model does not show the precise correlation between different variables of design and market orientation.

Design-oriented companies use design in generating the ideas and developing them into new products and services, processes, and even strategic positioning. This means that they have to be market-oriented, they need to think about market demand, about the competitors, and about the customer, including the customer's wishes, preferences, and needs, even the ones of which they are not aware. To prove links between market orientation and design orientation, the direct and indirect relationships are going to be investigated with several hypotheses. The initial conceptual model of relationships between market orientation and design orientation, with basic links, is shown in figure 1. Also, design-oriented companies and organizations are not always customerdriven because they have to predict trends and needs. But if we agree on the definition that design orientation describes a strategic managerial approach based on choosing design as a source of competitive advantage (Borja de Mozota, 2003b, 2009; Best 2006; Von Stamm, 2008; Brown, 2008), then we come to a conclusion that design orientation has a strong relationship with market orientation. Therefore, we propose:

H1: Companies that are more market oriented are also more likely to be design oriented.

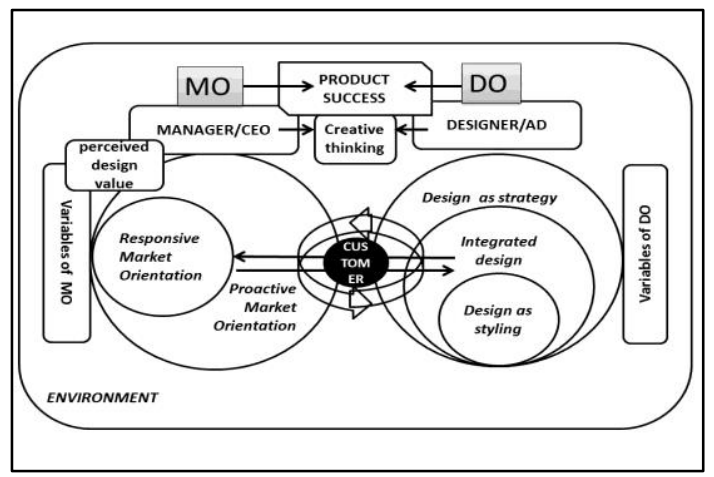

Fiqure 1: The development of a conceptual model with main links 


\section{Sanja Rocco, Aleksandra Pisnik \\ Focusing On Customer: Relationships Between Design And Market Orientation}

Every successful design concept starts with the user-the customer and his needs. There is strong evidence about this fact in many studies (e.g. British Design Council), as well as in case studies (Bloch et al., 2003; Borja de Mozota, 2003a; Srinivasan et al., 2006). The design-oriented companies give attention to their products from the design point of view, they observe and in this way follow the changes to understand user needs better. User-centered designers are usability focused and driven by human factors. They use intuition and empathy, but also a variety of research approaches, to understand users. In doing so, they adopt a holistic approach by looking at problems from a systematic point of view; they are integrative thinkers. Also, as noted above, they continuously improve the products or services they design through an iterative, process-driven approach. (Borja de Mozota\&Peinada, 2013). Also, the research mentioned above (Moll et al., 2007) shows that design-oriented companies have a strong emphasis on clients. They continually analyze their customers' current and future needs; in all of the companies within the study, this process serves as a means to capture new business opportunities. The emotional value of design, including the aesthetic element, is as important as functional. The ultimate success of a designoriented company is to capture customers' hearts, more than customers' minds (Vekantesh et al., 2012). Therefore, we propose:

\section{H2: Companies that are more design oriented are also more customer oriented.}

Further, several existing studies show that design-oriented companies are more open to creative managerial "design thinking." Tim Brown, one of the co-founders of IDEO, a design and innovation consultancy agency that promotes design thinking, defines the term as a discipline that uses the designer's sensibility and methods to match people's needs with what is technologically feasible and what a viable business strategy can convert into customer value and market opportunity (Brown, 2008). A market orientation appears to require a certain level of risk-taking on the part of senior managers and a willingness to accept occasional failures of new products and services as being a normal part of business life (Jaworski \& Kohli, 1993).

The design is the purposive application of creativity to all the activities necessary to bring ideas into use, either as a product (service) or as process innovations (Bruce \& Bessant, 2002). Empathy, integrative thinking, experimentalism, collaboration, and even optimism are learned skills that a designer integrates through a long process of learning by doing and applying. However, as Borja de Mozota (2009) argues, there is "design you can see" and "design you can't see." The former describes "the reality of design activity (through concrete design projects classified under many design disciplines, namely tangible design)," while the latter refers to "the definition of design activity (variously identified as the design science, design ethics, or design theory - all intangible things). Managers interested in design thinking approaches have to integrate design theories into their organizational theories and see design as sources of knowledge for designing their organization's platforms and structures (Borja de Mozota \& Peinado, 2013).

A qualitative empirical case study comprising 19 interviews with managers and designers was conducted to prove the potentials of design thinking. Stevens, Moultree, and Crilly (2008) document the results of this exploratory study of design's potential at the strategic level, and the difficulties faced by organizations in exploiting design strategically. It is suggested that design's strategic relevance can be considered in three ways: competing by high design can be a strategic position in itself; an integrated, coherent design approach can help to implement strategic positioning; design methods (so-called design thinking) can inform strategy formulation. Different approaches to the decision-making process is a universal problem that exists no matter how developed countries are (Borja de Mozota, \& Peinada, 2013). To conclude, therefore we propose:

H3: The managerial approach to a decision-making process in more design-oriented companies is significantly different from the one in non-design oriented companies. 


\section{Sanja Rocco, Aleksandra Pisnik \\ Focusing On Customer: Relationships Between Design And Market Orientation}

Successful design orientation is a company-wide phenomenon, and the best way to view a company is organically rather than structurally (Venkatesh et al., 2012). User-oriented design (UOD) increases collaboration through enhancing integration and providing a common point of reference for different disciplines involved in new product development (Veryzerand Borja de Mozota, 2005). Design's contribution to meeting business objectives, its role in business strategy, innovating, or in building the brands depends on its position in the company and its relationship with the management (Moll et al., 2007). Results from the case study research undertaken in 19 Swedish high-quality design companies (Venkatesh et al., 2012) prove that design orientation is not an isolated function, but that it represents a top-to-bottom execution of design philosophy throughout the organization's departments; therefore, we propose:

H4: Design oriented companies that have more inter-functional coordination inside the company also have design implemented at more levels.

\section{QUALITATIVE RESEARCH ANALYSIS}

In this paper, we analyze the results of the first qualitative stage of the research focused on design orientation of market-oriented companies. Two groups of respondents are included: managers and designers, through a series of qualitative, face-to-face interviews.

The sample of selected professionals was based on the assessment of the researcher, as typical representatives of the future examinees in quantitative research. Five selected top managers from different industries have been interviewed, as well as a selection of five designers, to provide an opinion from another perspective, in order to design the final questionnaire for quantitative research. With in-depth interviews we want to identify a possible difference in their approach to design, the managers' awareness of design potentials, their use of design thinking, their cooperation with designers, their knowledge about design management and, finally, their understanding of the relationship between design and market orientation. The interviews lasted between 45 minutes and an hour.

One of the selected managers is also a CEO, while two of them are top managers and two are marketing managers. They come from different fields - food industry (2), beverages (1), furniture industry (1), hotel industry (1). Three companies have between 51-100 employees, while two have more than 200. One designer is a freelancer, while three of them work in design studios (between 2 and five employees) and one is a creative director in a marketing agency (more than 31 employees). While one has between 6 and ten years of design experience, others have more than 11 years. The fields of design they cover are multiple, from communication design (all of them) to visual identity (4), interactive design (3), advertising (3), service design (3), interior (1), product (2) and design management (2). Most of them work for commercial clients, while one works mostly for noncommercial clients (culture). About their job, designers mostly negotiate with marketing managers (4) or CEOs (4) who usually are also managers and responsible for design in their company.

At the beginning of the interview, managers and designers have to define design in their own words. Both groups also evaluate the design characteristics by their importance for business performance. While managers are asked to also specify the areas and levels of design use in the company, designers are asked the same concerning their main client. A set of questions about marketing orientation is also discussed with the respondents.

For all the examined managers the most important driving force behind the product/service development is customer value, and, in their opinion, they measure customer satisfaction systematically, working closely with lead users to recognize customers' needs before the majority of the market. Also, for them, the most important elements of company's design orientation are the focus on customers and the use of creativity, as well as design thinking throughout the company. 


\section{Sanja Rocco, Aleksandra Pisnik \\ Focusing On Customer: Relationships Between Design And Market Orientation}

For them, the design creates a competitive advantage and added value, allows an opportunity to sell at a higher price, it innovates services accompanying products and differentiates a product or service from the competition. Their problems in communicating with designers are a different approach to design problems, lack of designers' creativity or professionalism, as well as different values and priorities. For designers, the meaning of company 's design orientation is the use of design in different levels, throughout the company, implementing design thinking and focus on customers and their needs, in order to improve their lives, as well as to contribute to the society. Most problems they are facing while working with managers are a lack of information and badly prepared design brief, misunderstanding of design problems and its potentials, as well as short deadlines.

Results show that managers estimate creative, competitive advantage of design as the most important element of design management, creating added value for the customers. Designers, on the other hand, consider improving external and internal communications, differentiation of products, and competitive business strategy as the most valuable characteristics of using design. While all of the five managers believe that they use design broadly in their companies, from corporate communications, branding, product, and service development to strategic planning, designers estimate that their clients use design mostly to a limited extent in specific areas, such as corporate communications, advertising, branding, and product development. However, there is not much difference in the meaning of design orientation between the two groups of examinees. Finally, both groups of examinees estimate the state of national design industry as moderate, lack of design policy and an unfavorable environment for design development.

\section{CONCLUSION AND FUTURE RESEARCH}

The qualitative stage deals with the potentials of design orientation from the managers', as well as the designers' perspectives. When analyzing the results, we come to a conclusion that differences between the two groups of examinees exist, mostly in their perception of design.

According to the Commission of the EU Communities' document (2013), the design should be a driver of innovation, especially in the SME sector, where the use of design is poor. Design management has become a broadly accepted strategic approach to innovativeness. It includes the use of design thinking, design methods, or even designers' sensibility to solve general business problems (Brown, 2009). However, the level of design implementation is not the same in every company, and there are specific reasons for different perceptions of design values, depending on, among other things, the top management approach to design. Similarities between marketing and design discussed by academics include design's focus on customer value, identification of new market opportunities, and design becoming a corporate philosophy directing all organizational activities. However, there remains a gap between design practice and theory on how design should be managed and integrated with other units. As seen in the literature surrounding the marketing-design relationship, opinions remain divided on whether the two functions should be integrated. In order to fully understand the value of marketing and design in organizational innovation, more research should be undertaken, as they help to provide a complete picture of the strategic importance of marketing and design for success in the market (Sun, 2012).

The proposed conceptual model, providing a new approach, extends current thinking by integrating market and design orientation towards strategic competitive advantage. The discussion strengthens the synergy effect of market and design orientation for better business performance. The model also provides the context for empirical research of direct relationships between market and design orientation as well as for indirect relationships with perceived value of design and its performance in the market. The limitation of the study is the complexity of the topic. It is not possible to investigate all the aspects of the problem. Also, the research is at an early stage. However, we suggest that this study provides a solid basis for future quantitative research. Another suggestion is to broaden research to other countries, enabling comparison of results, concerning different environment. 


\section{REFERENCES}

- Atuahene-Gima, K. (1995). An exploratory analysis of the impact of market orientation on new product performance. Journal of Product Innovation Management, Vol. 12, pp. 275-93, CrossRef

- Bagozzi, R. (2011). The evolution of marketing thought: From economic to social exchange and beyond (Chapter 14). The SAGE Handbook of Marketing Theory. Maclaran P., Saren M., Stern B. and Tadajewski M. (Editors), Sage Publications.

- Berthon, P.R., Hulbert, J.M., \& Pitt, L.F. (1999). Brand management prognostications. Sloan Management Review (winter), 53-65.

- Best, K. (2006). Design management: Managing design strategy, process, and implementation. Ava Publishing, Zurich.

- Best, K. (2010). Fundamentals of design management. Ava Bloomsberry.

- Black, C. D., Baker, M. (1987). Success through design. Design Studies. Vol. 8, No. 4, pp. 207-216, CrossRef

- Blaich, R. \& Blaich, J. (1993). Product design and corporate strategy - Managing the connection for competitive advantage. McGraw Hill, New York.

- Bloch, P.H., Brunel, F.F., \& Arnold, T.J. (2003). Individual differences in the centrality of visual product aesthetics: Concept and measurement. Journal of Consumer Research. 29, 551-565, CrossRef

- Bodlaj, M., Coenders, G., \& Žabkar, V. (2012). Responsive and proactive market orientation and innovation success under market and technological turbulence. Journal of business economics and management, vol. 13, no. 4, 666-687, CrossRef

- Borja de Mozota, B. \& Peinado, A. (2013). New approaches to theory and research in art \& design lead educational programs - Can "Design Thinking" sparkle new answers to old problems? CAA Conference, New York.

- Borja de Mozota, B. (2003a). Design management: Using design to build brand value and corporate innovation. DMI/Allworth Press, New York.

- Borja de Mozota, B. (2003b). Design and competitive edge: A model for design management excellence in European SMEs, Université Paris X Nanterre. Reprint \#02ABOR88, first published in Design Management Journal Academic Review, 2002, Vol.2, pp. 88-103.

- Borja de Mozota, B. (2009). Design management as core competency: From "Design You Can See" to "Design You Can't See". Journal of DMI, vol. 4.

- Borja de Mozota, B. (2011). Design economics-microeconomics and macroeconomics: exploring the value of designers' skills in our 21st century economy.17-39, CUMULUS // DRS SIG on Design Pedagogy 1st International Symposium for Design Education Researchers, Paris, 18-19.

- Brown T. (2008). Design Thinking. Harvard Business Review, June Issue, 86-93.

- Bruce, M. \&Bessant, J. (2002). Designing Business. Harlow. Financial Times/Prentice Hall.

- Bruce, M., Potter, S., \& Roy. (1995). The risks and rewards of design investment. Journal of Marketing Management, Vol 11, Issue 5, pp. 403-17, CrossRef

- Chitturi, R., Raghunattan, R., \& Mahajan, V. (2008). Delight by Design: The Role of Hedonic Vs Utilitarian Benefits, Journal of Marketing 72 (May): 48-63, CrossRef

- Coley, L. S., Mentzer, J. T., \&Coope, M. (2010). Is consumer orientation a dimension of market orientation in consumer markets? Journal of Market Theory and Practice, 18 (2), 141-154, CrossRef

- Commission of the EU Communities (2013). Implementing an action-plan for design-driven innovation. $\quad$ Retrieved 17 Aug. 2014 from: http://ec.europa.eu/enterprise/policies/innovation/policy/designcreativity.

- Deshpande, R. \& Farley, J. (1998). Measuring market orientation: generalization and synthesis. Journal of Market-Focused Management, Vol. 2 No. 3, pp. 213-32, CrossRef

- Design Council. (2004). Designing Britain 2005-2006. Available at: www.designcouncil.org.uk/factfinder, retrieved 25 May, 2008

- Dumas, A. \& Mitzberg, H. (1991). Managing the form, function and fit of design. Design Management Journal 2, (Summer), 26-31, CrossRef 


\section{Sanja Rocco, Aleksandra Pisnik \\ Focusing On Customer: Relationships Between Design And Market Orientation}

- Frosch, R. (1996). The customer for R\&D is always wrong! Research-Technology Management, November-December, pp. 22-27.

- Gemser, G. \& Leenders, M.A. (2001). How integrating industrial design in the product development process impacts on company performance. Journal of Product Innovation Management, Volume 18, Issue 1, pages 28-38, CrossRef, CrossRef.

- Grinstein, A. (2008). The relationships between market orientation and alternative strategic orientations: A meta-analysis. European Journal of Marketing, Vol. 42. Issue. 1/2, pp. 115134, CrossRef.

- Gumesson, E. (1991). Marketing orientation revisited: The crucial role of the part-time marketer. European Journal of Marketing, 25 (2), 60-75, CrossRef.

- Han, S.H., Yun, M.H., Kim, K., \& Cho, S. (1998). Development of a usability evaluation method. Technical Report (97-G-17-01-A-15), Ministry of Science and Technology of South Korea.

- Hertenstein, J., Platt, M., \& Veryzer, R. W. (2005). The impact of industrial design effectiveness on corporate financial performance. The Journal of Product Innovation Management, Vol. 22, No. 1, pp. 3-21, CrossRef.

- Jaworski, B.J. \&Kohli, A.K. (1993). Market orientation: Antecedents and consequences. Journal of Marketing, Vol.57 (July), 53-70, CrossRef.

- Kahn, K. B. (2001). Market orientation, interdepartmental integration, and product development performance. Journal of Product Innovation Management, Vol.18 No 5, pp. 314-323, CrossRef, CrossRef.

- Kohli, A., Jaworski, B., \& Kumar, A. (1990). Market orientation: The construct, research propositions and managerial implementations. Journal of Marketing, 54 (April), 1-18, CrossRef.

- Kohli, A., Jaworski, B., \& Kumar, A. (1993). MARKOR: A measure of market orientation. Journal of Market Research, 30 (4); 467-477, CrossRef

- Kotler, P. \&Rath, G. A. (1984). Design: A powerful but neglected strategic tool. Journal of Business Strategy, 5, 16-21, CrossRef

- Lafferty, B.A. \&Huit, G.T.M. (2001). A synthesis of contemporary market orientation. European Journal of Marketing, Vol. 35, No. 1/2, pp. 92-109, CrossRef.

- Moll, I., Montana, J., Guzman, F., Praallada, F.S. (2007). Market orientation and design orientation: A management model. Journal of Marketing Management, 23 (9): 861-876, CrossRef.

- Narver, J. \& Slater, S. (1990). The effect of a market orientation on business profitability. Journal of Marketing, 54 (3), 20-35, CrossRef.

- Narver, J.C., Slater, F.S., \&MacLachlan, D.L. (2004). Responsive and proactive market orientation and new-product success. The Journal of Product Innovation Management, 21: pp. 334-347, CrossRef

- Olson, E., Slater, S., \&Cooper, R. (2000). Managing design for competitive advantage. Design Management Journal, Vol. 11, No. 4, 10-17.

- Schmitt, B., Simonson, A. (1998). Coupling brand and organizational identities through planning. Design Management Journal, Vol. 9, no. 1, 9-14.

- Schroeder, J.E. (2002). Visual Consumption, New York, Routlege.

- Sisodia, R.S. (1992). Competitive advantage through design. Journal of Business Strategy, Vol. 13, No. 6, pp. 33-40, CrossRef.

- Slater, S. \&Narver, J. (1994). Does competitive environment moderate the market orientation-performance relationship? Journal of Marketing, Vol. 58, January, pp. 46-55, CrossRef.

- Slater, S. \&Narver, J. (1998). Customer-led and market-oriented: Let's not confuse the two. Strategic Management Journal, 19 (10), 1001-1006, CrossRef.

- Slater, S.F. \&Narver, J.C. (2000). The positive effect of a market orientation on business profitability: A balanced replication. Journal of Business Research, 48, 69-73, CrossRef. 
- Snoj, B., Milfelner B., \& Gabrijan, V. (2007). An examination of the relationships among market orientation, innovation resources, reputational resources, and company performance in the transitional economy of Slovenia. Can J Adm Sci, 24 (3), 151-164, CrossRef

- Srinivasan, R., Lilien, G.L., \& Rangaswami, A. (2006). The emergence of dominant designs. Journal of Marketing, 70 (April), 1-17, CrossRef

- Stevens, J., Moultrie, J., \&Crylli, N. (2008). Designing and design thinking in strategy concepts: Frameworks towards an intervention tool. International DMI Education Conference, Design Thinking, ESSEC, Cergy-Pointoise.

- Sun, S. (2012). Marketing and design in organisational new product development. Master Thesis, Victoria University of Wellington, School of Marketing and International Business.

- Ulrich, K.T. \& Pearson, S. (1998). Assessing the importance of design through product archaeology. Management Science, 44 (3), 352-369, CrossRef

- Venkatesh, A., Digerfeld-Mansson, T., Brunel, F.F., \& Chen, S. (2012). Design orientation: A grounded theory analysis of design thinking and action. Marketing Theory, 12 (3), 289-309, CrossRef

- Veryzer, R.W. \&Borja de Mozota, B. (2005). The impact of user-oriented design on new product development: An examination of fundamentals relationship. Journal of Product Innovation Management, 22 (March), 128-143, CrossRef

- Von Stamm, B. (2008). Managing innovation, design and creativity. John Wiley and Sons Ltd. 